\title{
Research on Cultivation Model of E-commerce Talents in Higher Vocational Colleges Oriented for "One Belt and One Road"
}

\author{
Jingjing $\mathrm{Li}^{1 \text {, a }}$ \\ ${ }^{1}$ Shaanxi Institute of International Trade \& Commerce, Xi'an, 712046, China \\ ${ }^{\mathrm{a}}$ email
}

Keywords: One Belt and One Road, Higher vocational colleges, E-commerce talents

\begin{abstract}
The policy of "One Belt and One Road” puts forward new demands for e-commerce talents training in higher vocational colleges in China. E-commerce talents should possess the language competence, information technology and professional quality. Therefore, we must optimize curriculum system, strengthen practice exercise and improve teacher team in higher vocational colleges to cultivate new e-commerce talents.
\end{abstract}

\section{Introduction}

"The Belt and Road East Chinese, throughout Central Asia, Southeast Asia, South Asia, West Asia, leading to the heart of Europe, is a big economic corridor across the Eurasian continent. Covering the Asia Pacific Economic Circle and the European economic circle, the influence has even reached parts of America and Oceania. Within this range, the national and regional economic complementarities are strong, and the degree of industrial relevancy is high. Relying on resources, industrial and cultural aspects of the complementary advantages, can effectively expand trade and investment space, to China western, Central Asia, West Asia and other regions to bring the new opportunity of deep development, at the same time for China financial development, RMB internationalization strategy also has a positive effect. In the global economic recovery is still in the post financial crisis era, lack of power, "The Belt and Road" strategy to the world economy will undoubtedly play a booster. The cross-border electricity supplier is a new pattern of "The Belt and Road" pilot and the breakthrough point. However, the severe scarcity of cross-border electricity supplier talent has become the key factor restricting the development of cross-border electricity industry in China, so the analysis of training needs of domestic and cross-border e-commerce development present situation and talent, has important significance to further explore the cross-border electricity supplier training measures. Cross border electricity supplier talent training is the urgent need of cross-border electricity supplier industry development, but also a major direction of talent training in Higher Vocational colleges. With professional and excellent cross-border e-commerce talents, we can achieve the perfect integration of the entity and the virtual market. In recent years, due to the cross-border e-commerce is a new industry, the lack of talent stock, with experience and practical ability of outstanding talent is rare. With the rapid development of cross-border e-commerce, the demand for related talents is more urgent. However, colleges and social training institutions in cross-border e-commerce personnel training is not in place, the relevant education is based on theory, and business practice disjointed, training of talent is not competent for related work. The shortage of talent and the lack of supply have led to a widening of the gap in talent.

\section{Requirements for E-commerce Talents in Higher Vocational Colleges of "One Belt and One Road"}

Language Competence. In the cross-border e-commerce process, whether it is website promotion, online trading platform application, product introduction, correspondence processing, access to information, customer service customer service and other translation work, or online communication, call to negotiate with foreign customers or require cross-border electricity supplier practitioners must have certain English reading, writing and oral communication skills. Second, the cross-border 
electricity supplier transactions are different from each other, and the online platform operation, product introduction, marketing, order processing and other operations need good foreign language ability. Cultivation of talents to highlight cross-border business English training student's ability to transport month, product, the customer exchange, order processing, writing articles and other social media actual ability to use foreign language in English on the trading platform. Since the new Chinese established, China's colleges and universities of English as the major language education into a larger, while the Belt and Road Initiative along the country's investment is not enough. The Belt and Road "covered along the Central Asia, South Asia, West Asia and other regions of the official language of awn up to 40 kinds of non-language month talent gap, cannot meet the need of a road under the sponsorship of the trade flow, therefore need to intensify efforts to train talents with basic Ji Tong cross-border communication ability in foreign language, form" English language $+X$ "language ability, large cross-border electricity providers to eliminate language barriers, increase communication initiative.

Information Technology. Network information technology application ability cross-border electricity supplier is based on network information technology, online transactions as the core business activities. Therefore, practitioners must have certain application ability of network information technology, master the operation management of network shop, the use of e-commerce network tools and other skills. Also need powerful computer application ability, to be familiar with data statistics software, web design software, beauty software need to involve. No matter is the construction of cross-border business trading platform, or through the third party platform to engage in cross-border transactions, both need to be able to conduct product data on the platform, you like editing production, products shelves optimization, to improve search traffic and other electric business operations and a series of Emirates, the cross-border electricity supplier talent first need to have computer and information technology the Internet and database operation ability. Comprehensive cultivation of Higher Vocational Students' use of computers, the use of computer, let the computer to help us solve the problem of thinking habits, develop good learning habits this is only the first layer of the level of our teaching; the second layer is the use of our advanced ideology in the field of computer knowledge to enhance our students' modern consciousness, independent consciousness and awareness the third layer; using the computer field has some distinctive examples to our higher vocational students propaganda, education and cultivate the patriotic consciousness and the sense of historical responsibility and mission. "Stereo" refers to our computer education not only is the use of unified teaching materials to educate the students, more important is to through a variety of materials and a variety of ways to provide vocational students to spread, represented by computer advanced the concept of social publicity.

Professional Quality. "Belt and Road Initiative" strategy, the huge differences in foreign languages, customs, culture, policy is a problem in front of cross-border e-commerce enterprises. There is a huge shortage of cross-border e-commerce talents who have both e-commerce skills and expertise in foreign trade, while mastering the language of the countries concerned, and understanding the local consumers' ideas and cultures. Enterprises attach great importance to the cultivation and improvement of staff's comprehensive quality, such as team cooperation ability, communicative ability, strain ability, innovation ability. Colleges and universities can make full use of the platform of moral education to help and guide students to establish a correct outlook on life and values. Through the organization of various team activities, quality development activities, let students experience the strength of the team in the activities, set up the sense of teamwork. To provide students with optional courses and community activities of quality education, and encourage students to participate actively. At the same time, it can also carry out social practice activities, which can not only cultivate students' sense of social responsibility, but also improve their social communicative ability. In addition to the above mentioned technical skills, cross-border electricity supplier industry also put forward high requirements for the professional quality of talents. Cross-border business is facing the customers from all over the world are different in language, education, culture, politics, religion, life style, consumption environment, consumer psychology and other factors, makes the cross-border e-commerce become more complex. This requires employees to have flexible ability to 
handle affairs, good communication skills, practical work attitude and actively cooperate with the team consciousness.

\section{Reform Measures of E-commerce Talents in Higher Vocational Colleges}

Optimize Curriculum System. Actively explore a new model of cross-border electricity supplier personnel training should strive to cultivate university, with international trade, cross-border e-commerce, network marketing, customer service, logistics services and other professional skills, high-quality talents with strong practical ability, sustainable development ability and creative spirit. Pay close attention to the development of cross-border electricity supplier industry trends, through visits of cross-border business, foreign trade companies, factories, online information collection and other means, to carry out cross-border electricity and post occupation personnel demand investigation, determine the training goal of cross-border electricity supplier personnel, and enterprise cooperation with the development of cross-border electricity supplier training program. The study of theoretical knowledge can be combined with the teaching of professional skills, and in the process of learning foreign trade professional skills, the actual work needs of cross-border e-commerce enterprises should be taken into consideration, and the "zero docking" can be realized". General education curriculum emphasizes the basic and application ability, focusing on strengthening computer, English, international communication, art, literature and other courses. To improve the professional ability of English use, each semester should be related to English courses, especially the listening and speaking course. The basic course of discipline emphasizes the mastery of professional basic knowledge, including management, economics, statistics, introduction to cross-border e-commerce, international trade practice, database principles and applications, business circulation and other courses. Professional courses focus on improving the application ability of cross-border electricity providers, the courses include: brand management, website promotion, data analysis, cross border e-commerce copy planning, e-commerce project analysis and design. Professional optional courses focus on broadening students' knowledge and enhancing students' team communication and coordination ability.

Strengthen Practice Exercise. College-enterprise cooperation is an eternal topic in the teaching reform of cross border electricity supplier. How to put the practical experience and the theory teaching at the same height, make the enterprise really play a role in guiding the school professional teaching is the key problem. Establish an off-campus training base with enterprises, build a practical teaching system, organize students to enter the cross-border e-commerce enterprises for short-term or long-term professional training. For example, according to the task needs of each teaching stage and the different levels of students' cognitive level, the students should be arranged in turn to practice teaching in the school enterprise cooperation training base. The school classroom teaching and extracurricular training base practice organically combined, so that enterprises really involved in teaching, using the enterprise model to guide the teaching, to truly realize the employment of secondary vocational students to prepare. China's development is still in an important period of strategic opportunities, and accurate judgment of important strategic opportunities is an important guarantee to win the future. In the "The Belt and Road" strategy under the background of the situation, the development of cross-border e-commerce, cross-border e-commerce professional students must use their own professional advantage, have enough knowledge to emerge in the business, the new business field. Cross border electricity supplier requires high practical ability of talents, and the integration mode of production and education is an effective means to improve the practical ability of talents. But the traditional integration of production and education while encouraging students to participate in the actual operation of the enterprise, but because there is no clear who is responsible for who, from which links started to teach, teach the lack of systematic, the students really learn something small and miscellaneous, hit the enthusiasm of the students, cannot achieve the business skill requirements, lead to the integration of production and education the effect is not ideal. "Teacher apprentice" mode of production and teaching refers to the practice of college students with rich experience of the old staff, while practice and learning skills. Carry out the division with only work, 
can be as a "master" veteran of years of practical experience, methods and ideas in a relatively short period of time to teach students, so that they can master the corresponding job skills as soon as possible, improve the training enthusiasm. At the same time, the characteristics of the students is to master the theoretical knowledge of the latest ideas, unique creative, through the development of the acquisition of the division with only "work for enterprise employees further enhance the theoretical knowledge and related information is also of great help.

Improve Teacher Team. Cross border e-commerce professional teachers should have foreign trade knowledge and electricity supplier knowledge, but also have a wealth of practical experience. Cross border electricity supplier teaching team is an important support for talent training. Therefore, we should take the "go out, please come in" way to increase the cross-border electricity supplier professional teachers training. There are plans to arrange professional teachers to go out to participate in a variety of cross-border business training and learning, can also invite cross-border e-commerce enterprises or foreign trade industry practitioners, training seminars for teachers' professional knowledge, optimize the structure of teachers, improve the learning ability of professional teachers. At the same time associated with the "The Belt and Road" national universities to strengthen ties and carry out teacher access and student exchange projects, improve teachers' level of theory and practice, openness, the times of school. The quality of teachers determines the quality and effectiveness of teaching, directly affecting the realization of the goal of personnel training, cross-border electricity business requires many teachers with practical experience, therefore, from multiple channels to build a team of teachers. First, through the establishment of teacher training mechanism in schools and enterprises, the regular arrangements for full-time teachers to enterprise training, training teachers' practical ability, the construction of double teachers and dual energy teaching team. Two is from the enterprise to introduce cross-border electricity supplier practical experience of the industry mentor, to the school to teach students' post skills, participate in the school curriculum preparation, promote the deep cooperation between school and enterprise. The three is to organize professional teachers to participate in the national and international electricity supplier academic exchange conference, master the industry forefront information, encourage teachers to assume or participate in the research of electronic business, improve academic level. The four is to strengthen and The Belt and Road along the country's college academic exchanges, the establishment of the "The Belt and Road along national college school system, scholars to other institutions for further study, improve the teachers' cognition of" the Belt and Road along the country's economic and trade activities.

\section{Conclusion}

The national "Belt and Road" initiative, the rapid development of electronic business, personnel training has become the urgent need to address the problem of talent is different from the traditional electricity supplier personnel, international personnel training needs and cross-cultural communication ability, strengthen the different disciplines and integration, the establishment of the integration of e-commerce, marketing, international trade, computer professional curriculum modules, through the division with only the integration of production and education mode of precision improving personnel training with practical ability, can combine the theory and practice, to solve practical problems of the professional knowledge of international talent, "The Belt and Road initiative under the trade flow continued to provide intellectual support.

\section{Acknowledgment}

This paper is the result of Research on Talent Cultivation Mode Reform of E-commerce Major in Higher Vocational Colleges with Work-Study Combination as the Breakthrough Point. 


\section{References}

[1] Wang Juanjuan, Qin Wei. Explore the New Normal of E-commerce in the "One Belt and One Road” Strategic Area [J]. China Business and Market, 2015(5): 46-54.

[2] Cheng Rang. The Promotion of Business English Talents to the Cross-Border E-Commerce Industry under the Strategy of" “One Belt One Road” [J]. The Border Economy and Culture, 2016(8): 10-11.

[3] Wang Qiong. Study on the Cultivation Path of Cross-border E-commerce Talents in Colleges and Universities under the Background of "the Belt and Road" - Taking Hangzhou as an Example [J]. Higher Vocational Education- Journal of Tianjin Vocational Institute, 2017, 26(1): 44-47+68.

[4] Su Ge. The Belt and Road Initiative in Global Perspectives [J]. China International Studies, 2016(2): 5-27. 